\title{
A GÊNESE DAS HOSTILIDADES ENTRE O IRÃ E OS ESTADOS UNIDOS.
}

\author{
THE GENESIS OF HOSTILITIES BETWEEN \\ IRAN AND THE UNITED STATES
}

\author{
Tamires Maria Alves ${ }^{1}$
}

\begin{abstract}
Resumo: Procura-se entender o que levou o Irã a passar de um papel de aliado ao de inimigo dos Estados Unidos. O ponto de ruptura entre estas nações ocorreu, segundo a visão norte-americana, no ano de 1979 com a Revolução Iraniana, em contrapartida para o Irã se deu em 1953 com o Golpe de Estado que depôs Muhammad Mossadeq. Tenta desnaturalizar a imagem ameaçadora do Irã. Para isso utiliza-se a teoria pós-colonial, uma vez que se acredita que a dominação econômica do Ocidente sobre o Oriente foi capaz de abarcar também a dominação cultural destes povos.
\end{abstract}

Palavras-chave: Irã; Mohammad Mossadeq; Petróleo; Reza Pahlavi; Operação AJAX.

\begin{abstract}
Seeks to understand what has led Iran from being an ally to an enemy of United States. The breaking point between these nations occurred, according to the American vision, in 1979 with the Iranian Revolution, in contrast to Iran, it happened in 1953 with the coup d'état that ousted Muhammad Mossadeq. It tryes to denaturalize this threatening image that Iran. Postcolonial theory will be used, since the postcolonial authors believe that the economic domination of the West over the East, made possible mainly by colonialism, was able to encompass the cultural domination of these people.
\end{abstract}

Keywords: Iran; Mohammad Mossadeq; Oil; Reza Pahlavi; AJAX Operation.

\section{INTRODUÇÃO}

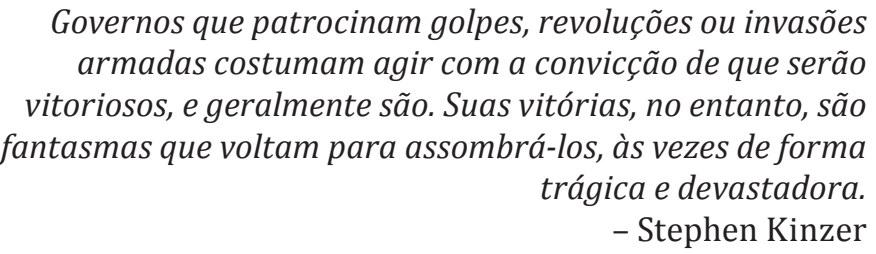

Esse trabalho pretende versar sobre a criação da ideia de que o Irã é uma ameaça. A criação da relação de hostilidade entre os Estados Unidos e o Irã se deu em dois momentos distintos. 0 primeiro momento, do qual trataremos neste capítulo, se dá após o Golpe de Estado financiado pelos norte-americanos em 1953 e marca a ocasião na qual parte significativa da população iraniana (setores progressistas e também setores religiosos islâmicos que atualmente compõe o regime dos aiatolás) passa a ter os Estados Unidos como inimigo. Vale destacar que não houve rompimento de relações entre o governo iraniano e os EUA

\footnotetext{
1 Doutora em Ciência Política pela UFF. Áreas de interesse: Construção de ameaças; Violência; Pós Colonialismo. Link Lattes: http://lattes.cnpq.br/3676097596765527. ORCID iD is 0000-0002-2608-7015. E-mail: tamiresmalves@gmail.com
} 
com a deposição de Mossadeq em 1953, mas o surgimento de um sentimento anti-estadunidense por parte desses setores.

O segundo momento, por sua vez, é em 1979, quando os Estados Unidos passam a perceber no Irã uma ameaça real, o que não será explicitado neste trabalho. Como elucidado, buscaremos perceber como a caraterização do Estado iraniano pelos norte-americanos como um Estado ameaçador é datado, através de uma mudança da postura iraniana em relação a determinados aspectos que desafiavam a lógica da modernidade (Alves, Tamires, 2013).

Para compreender a ascensão e a queda do governo democrático de Mohammad Mossadeq, é necessário retornar para 1950. Após o fim da Segunda Guerra Mundial, era notória a apreensão na comunidade internacional de que houvesse a eclosão de uma nova guerra. Como ambas as potências (Estados Unidos e União Soviética) continham armamento nuclear ${ }^{2}$, este possível confronto Leste-Oeste determinou o início da Guerra Fria (Kinzer, Stephen, 2010: 104).

A nacionalização do petróleo iraniano em março de 1951 não foi uma célere decisão. Somente quando Mossadeq chega ao poder como primeiro-ministro é que o país estatiza a empresa. É importante levar em consideração a figura pública de Mossadeq. Seu carisma e caráter impulsivo são ilustrados em passagens de diversos autores. Karen Armstrong faz uma comparação sobre como Mossadeq era visto pelos distintos países.

$\mathrm{Na}$ Inglaterra e nos Estados Unidos a mídia apresentou Mossadeq como um fanático perigoso, um ladrão (apesar de ele ter prometido indenização), um comunista que entregaria o Irã à União Soviética (embora ele fosse um nacionalista empenhado em libertar seu país de toda dominação estrangeira). Para seus compatriotas, no entanto, Mossadeq era um herói, mais ou menos como Nasser depois de nacionalizar o canal de Suez (Armstrong, 2001: 262).

\section{MOSSADEQ, A NACIONALIZAÇÃO DA AIOC E A OPERAÇÃO AJAX}

Mossadeq era tido como "o pai da nação", "patriota da Pérsia" (Bellaigue, Chistopher de, 2002: 164), “carismático" (Limbert, John W, 2009: 64), “herói do Irã" (Coates, Ken, 2006: 4), entre outros adjetivos. Segundo Roy Parviz Mottahedeh:

Para seus muitos admiradores, Mossadeq era inquestionavelmente um leão de Deus e um herói como Rostam ${ }^{3}$, filho de Zal. Mas para todos os iranianos admiradores e depreciadores - , ele era mais: Ele era a pedra angular, o campo magnético, o para-raios que ficava cronologicamente e intelectualmente no centro da política iraniana do século XX. Quase todo mundo foi puxado ou empurrado,

\footnotetext{
2 Vale ressaltar que durante a Guerra Fria algumas instituições fundamentais para a história iraniana foram criadas. Estas instituições foram a Agência Central de Inteligência (CIA), fundada em 1947 para fiscalizar informações que afetassem a segurança nacional, e a Organização do Tratado do Atlântico Norte (OTAN), criada em 1949, que mesmo tendo 11 membros participantes, tinha como base a aliança entre Estados Unidos e Grã-Bretanha. A invenção da CIA foi crucial para o golpe que o primeiro-ministro iraniano levaria em 1953 (Kinzer, 2010: 104). Já a OTAN tinha como objetivo naquele momento se opor ao bloco comunista e celebrar uma cooperação entre os seus membros, caso algum deles fosse atacado pelos inimigos.

3 Herói da antiga Pérsia que foi imortalizado pela obra Shāhnāma, ou "Épico dos Reis" de Ferdowsi, século X.
} 
atraído para dentro ou repelido para fora de sua órbita. Praticamente ninguém passou pelo período de sua influência sem ser afetado por sua presença. Ele estava entre o primeiro aluno e os primeiros professores iranianos da nova Escola Iraniana de Ciência Política, era especialista em instituições políticas europeias e, quarenta anos após sua graduação, assumiria o Irã em meados do século XX para ensinar sua interpretação um pouco idiossincrática da constituição que ele amara em sua juventude. Ele, o aristocrata, o descendente da dinastia Qajar, chegaria mais perto do que qualquer outra pessoa antes de 1978 a terminar a tradição iraniana da monarquia. Um homem cuja formação intelectual havia sido concluída muito antes de Reza Shah, Mossadegh era o produto final, o último e o mais impressionante da tradição liberal e nacionalista dos reformadores do século XIX (Mottahedeh, 2004: 15-16, tradução nossa).

Todavia, esta mesma personalidade era vista de maneira distinta pelos ingleses, que os descreviam como alguém que "governava irresponsavelmente, baseado em emoções" e que "cooperava com o partido comunista Tudeh" (Wilber, Donald N, 2006: 13). Vale lembrar que por parte das nações ocidentais, o comunismo era percebido muitas vezes como uma ideologia irracional.

Segundo Azimi, apesar das acusações inglesas, nem mesmo os desafetos de Mossadeq o acusavam de ser corrupto ou de criar leis em benefício próprio (Azimi, Fakhreddin, 2009: 333). Elm alega que o caráter de Mossadeq costumava ser reconhecido por eles, como ressaltado a seguir:

0 público em geral, no entanto, ficou impressionado quando Mossadeq, ele mesmo um aristocrata fundador, iniciou projetos que não eram para sua própria vantagem ou da classe. Ficou ainda mais impressionado quando Mossadeq, primeiro como vice de Majlis e depois como primeiro-ministro, doou todo o seu salário para instituições de caridade. Até o embaixador britânico Shepherd, que o odiava, nunca contestou sua incorruptibilidade ou a de seus colegas de gabinete (Elm, 1992: 274).

Mossadeq tinha orientação nacionalista, o que resultava numa espécie de aversão aos que não colaborassem com a manutenção dos recursos iranianos serem unicamente explorados pelo país. Em razão de tal, os Estados que possuíam maior descredito de Mossadeq eram a Inglaterra e a Rússia ${ }^{4}$, pois anteriormente haviam dividido o território iraniano. Todavia, esse distanciamento não era alimentado em relação aos Estados Unidos, pois os norte-americanos que conhecia eram em geral missionários ${ }^{5}$, dirigiam escolas, hospitais, entre outras instituições.

De fato, os acordos celebrados entre o Irã e os Estados Unidos foram amistosos durante mais de um século. Isso fez com que, no imaginário dos iranianos, os Estados Unidos fossem vistos como uma potência benigna. Entretanto, depois do golpe de 1953 nasce um sentimento de descontentamento por parte dos iranianos sobre os norte-americanos. Segundo Kinch, “o golpe de 1953 certamente poderia ser visto como um exemplo de dois lados interpretando

\footnotetext{
4 Segundo Kinzer, "Grã-Bretanha e Rússia haviam pisoteado a soberania iraniana durante mais de um século, e esta era a razão pela qual muitos iranianos passaram naturalmente a odiá-los" (Kinzer, 2010: 104).

5 Até o início do século XIX muitos missionários norte-americanos foram enviados ao Oriente Médio. Até 1895 eles possuíam quatrocentas escolas, nove liceus, nove hospitais e dez dispensários no Oriente Médio (Filiu, 2012: 63).
} 
um evento de maneira muito diferente. O golpe de Mossadeq marca o fim do amplo apoio popular no Irã à política americana" (Kinch, 2016: 44, tradução nossa).

Isso se sustenta a tal ponto que, após a Revolução Iraniana de 1979, e a ascensão do regime dos aiatolás, estes passaram a intitulá-los de “Grande Satã”. Como também destaca Kinch:

\begin{abstract}
Em todas as inúmeras entrevistas de pesquisa realizadas, conduzidas no Irã e com iranianos da diáspora, a invocação do golpe da CIA emergiu em cada um como uma contribuição central para o desenvolvimento da identidade política iraniana desde então. Este evento, o primeiro de muitos executados pela CIA desde seu início em 1947, teve um significado avassalador para a psique iraniana (Kinch, 2016: 43, tradução nossa).
\end{abstract}

Mossadeq era tido como um líder eloquente e nacionalista. Por conta do seu alegado carisma, em geral, suscitava o apoio dos cidadãos iranianos. Durante o período que governou o Irã, pareceu procurar estabelecer a democracia e combater a influência dos países que enxergava como imperialistas (Kinzer, 2010: 70-78). De acordo com suas palavras, a exploração estrangeira não era positiva de nenhum modo para país.

Se fosse bom para o povo trazer prosperidade ao país por meio do trabalho de outras nações, todas as nações convidariam estrangeiros para entrar em sua casa. Se a submissão fosse benéfica, nenhum país submisso teria tentado se libertar com guerras sangrentas e enormes perdas (Mossadeq apud Kinzer, 2010: 76).

A visão que Mossadeq e a maioria dos iranianos tinham da Inglaterra era tão pejorativa quanto à visão dos ingleses sobre o Irã e seus cidadãos. Os iranianos atribuíam à Inglaterra predicativos como "egoísta", "gananciosa", "imperialista”, entre outros (Polk, William R, 2009: 175). Com isso, é possível perceber os iranianos apenas invertiam a hierarquia de valores, transparece aqui então, uma relação de hostilidade mútua.

Os problemas entre Irã e a Inglaterra se agravaram com a eleição de Mossadeq para o cargo de primeiro-ministro. Numa passagem do livro de Limbert, o autor descreve como a escolha por Mossadeq somente acirrou os conflitos, uma vez que passaram a ver este líder como o centro dos problemas. 0 autor afirma que mesmo os ingleses que enxergavam problemas nos contratos da AIOC se tornaram irredutíveis, porque percebiam essa mesma irredutibilidade por parte de Mossadeq. A partir daí muitos ingleses passaram a acreditar que o problema central das negociações não estava apenas nos royalties do petróleo, nos livros de contas e nas taxas, mas sim na figura do primeiro-ministro. Dessa maneira, se inicia um ciclo de desentendimentos (Limbert, 2009: 63).

Com a nacionalização da Anglo Iranian Oil Company por Mossadeq, os conflitos entre Irã e Inglaterra se acirram. As declarações públicas da mídia inglesa atacavam o Estado iraniano e Mossadeq, atribuindo-lhes muitas das características orientalistas, como fraqueza, decadência e infantilidade. Segundo Polk, os ingleses atribuíam o entendimento dos iranianos sobre qualquer temática apenas a partir do uso da força ou do suborno (Polk, 2009: 175). Por conta dos discursos de Mossadeq, alegavam ainda que se tratava de um sujeito 
"lunático", "demagogo", "irracional” e "anormal”' (Azimi, 2009: 333-335). A insatisfação da Inglaterra com Mossadeq pode ser vista como uma reação à sua atitude pouco influenciável, o que em geral não ocorria com os primeiros-ministros anteriores. Podemos perceber isso na declaração publicada pela The Times assim que a AIOC foi nacionalizada:

A tensão interna da sociedade persa - causada pela estupidez, ganância e falta de julgamento da classe dominante (presumivelmente incluindo o aristocrata Mossadeq) - tornou-se tal que só pode ser suprida por uma aceleração do impulso contra o bode expiatório externo. - Grã-Bretanha7 (Tradução nossa).

Mossadeq, como supracitado, percebia a Inglaterra como uma antiga metrópole, visto que influenciava o Irã e suas elites locais como se esta tivesse de fato, sido sua antiga colônia. No seu primeiro discurso como primeiro-ministro, atacou os ingleses e a antiga AIOC, ao afirmar que "Toda a miséria, a desgraça, a anarquia e a corrupção dos últimos cinquenta anos, foram causadas pelo petróleo e pela extorsão da companhia petroleira" (Kinzer, 2010: 111). Mossadeq chegou a afirmar que os ingleses saquearam a principal fonte de riquezas do Irã por décadas, pagando subornos a governantes fantoches e que, apesar disso, ainda esperavam que o Irã os compensasse por perderem suas futuras pilhagens (Elm, 1992: 285).

0 embate entre as nações a respeito da nacionalização da companhia petrolífera chegou a ser levado pela Inglaterra às Nações Unidas, todavia esta deu parecer favorável aos iranianos $^{8}$. Dessa forma, a Inglaterra não deu seguimento ao caso (ALVES, 2018).

Depois da nacionalização da AIOC, os iranianos não tinham trabalhadores capacitados para dirigir a companhia. Por mais que oferecessem empregos para qualquer cidadão nacional ou estrangeiro (exceto ingleses) para trabalhar na petrolífera, também requeriam que as empresas estrangeiras lhes oferecessem cursos para aprender a refinar o petróleo no maquinário agora estatizado da AIOC. 0 governo iraniano fez tentativas de contratar os serviços terceirizados de outras companhias, todavia, o embargo inglês a estes potenciais

\footnotetext{
${ }^{6}$ Os termos utilizados pelas nações ocidentais para caracterizar Mossadeq são destacados nesse capítulo para que fique explícito o orientalismo presente de forma cultural que atravessa também as decisões políticas tomadas à época. Como destaca Said: "se presta muito pouca atenção ao papel da cultura na manutenção dos impérios. Joseph Conrad foi uma das testemunhas mais extraordinárias disso. Ele compreende que o lucro não está exatamente no cerne da ideia do império, embora certamente seja um dos motivos. Mas o que distingue os impérios antigos - como o romano, o espanhol ou os árabes - dos impérios modernos, entre os quais se destacam o britânico e o francês do século XIX, é que estes são iniciativas sistemáticas, com um reinvestimento constante. Eles não chegam a um país, saqueiam-no e vão embora quando a pilhagem termina. E os impérios modernos requerem, como afirmou Conrad, uma ideia de colaboração, uma ideia de sacrifício, uma ideia de redenção. Com isso obtemos noções bastante reforçadas de, por exemplo, no caso da França, mission civilisatrice (missão civilizatória), de que não estamos lá para nos beneficiar; estamos lá em prol dos nativos (Said, 2013: 69-70).

7 Fonte: The Times, April 14, 1951.

${ }^{8}$ No livro de Elm, o autor alega que a Corte Internacional de Justiça não foi a favor da nacionalização do petróleo. Apenas aceitou o argumento iraniano de que aquele caso não deveria ser julgado na Corte Internacional de Justiça das Nações Unidas, uma vez que não era um acordo celebrado entre dois países, mas sim entre um país (Irã) e uma empresa (AIOC) (Elm, 1992: 214). Já no livro de Polk, o autor argumenta que tanto a Corte Internacional de Justiça quanto os Estados Unidos foram a favor da nacionalização da companhia (Polk, 2009: 177).
} 
investidores e compradores de petróleo os fazia recuar da oferta iraniana (Limbert, 2009; Axworthy, Michael, 2008).

Com a falta de técnicos para manter a companhia funcionando, o Irã parou de vender petróleo, uma vez que era incapaz de produzi-lo. Para agravar a situação, os ingleses também realizaram um embargo de alimentos e bens ao Irã. Navios posicionados na costa do Golfo Pérsico impediam os iranianos de importar bens e de exportar petróleo (Polk, 2009: 178; Axworthy, 2008).

O aumento do preço dos alimentos colaborou para agravar a situação iraniana. A pobreza foi crescendo no país e, por conseguinte, Mossadeq foi perdendo popularidade. A implementação de uma série de reformas sociais e a fundação de instituições democráticas por parte do governo também não agradou as elites. Essas reformas no contexto da Guerra Fria geraram entre os estrangeiros a percepção do Irã como um aliado do bloco comunista (Elm, 1992: 273-275).

A tabela a seguir mostra a situação precária da balança de pagamentos do Estado iraniano:

Tabela 4: Balança de Pagamentos do Irã, 1949-1954 (em milhões de rials)

\begin{tabular}{|c|c|c|c|c|c|}
\hline Anos & $\mathbf{1 9 4 0 - 5 0}$ & $\mathbf{1 9 5 0 - 5 1}$ & $\mathbf{1 9 5 1 - 5 2}$ & $\mathbf{1 9 5 2 - 5 3}$ & $\mathbf{1 9 5 3 - 5 4}$ \\
\hline $\begin{array}{c}\text { Saldo líquido do setor } \\
\text { petrolífero }\end{array}$ & 4,024 & 3,902 & 1,026 & $\mathrm{X}$ & $\mathrm{X}$ \\
\hline Setor não petrolífero & & & & & \\
\hline Exportações & 1,244 & 2,11 & 2,71 & 2,807 & 3,075 \\
\hline Importações & $-6,831$ & $-6,427$ & $-5,686$ & $-3,829$ & $-5,666$ \\
\hline Serviços (líquido) & -419 & -169 & -175 & -100 & 149 \\
\hline Balança & $-6,006$ & $-4,486$ & $-3,151$ & $-1,122$ & $-2,442$ \\
\hline Balança de Conta & $-1,982$ & -584 & $-2,125$ & $-1,122$ & $-2,442$ \\
\hline Corrente & 886 & 739 & -327 & 465 & 3,439 \\
\hline Conta de Capital & $-1,096$ & 155 & $-2,452$ & -657 & 997 \\
\hline Saldo Total & & & & & \\
\hline
\end{tabular}

Mossadeq cortou relações diplomáticas com os ingleses em 1952 e determinou que todos se retirassem do Irã após descobrir que os ingleses negociavam um golpe contra o Estado. Esse foi o momento da entrada dos Estados Unidos no conflito. Uma vez que nenhum cidadão inglês poderia estar em solo iraniano, era preciso ter a colaboração de agentes norte-americanos (Coggiola, Osvaldo, 2008: 39).

Primeiramente, o Estado norte-americano foi a favor da nacionalização da AIOC, como relatado no documento do Departamento do Estado: "The administration of President, Harry 


\title{
S. Truman, initially had been sympathetic to Iran's nationalist aspirations" ${ }^{\prime 9}$. Documentos da
} CIA também apresentam como Truman não era contra a nacionalização:

\begin{abstract}
Em 1951, o governo iraniano, liderado por seu primeiro-ministro nacionalista de 69 anos, Mohammed Mossadeq, nacionalizou a Companhia de Petróleo Anglo-Iraniana, que fornecia $90 \%$ do petróleo da Europa. O governo britânico, acionista majoritário da empresa, ficou furioso e começou a procurar maneiras, incluindo ações militares, de derrubar o governo de Mossadegh. Mossadegh ficou sabendo das conspirações, no entanto, fechou a embaixada britânica e expulsou cidadãos britânicos do país. Sem uma base de operações no Irã, os britânicos se voltaram para o presidente Truman. Embora preocupado com o fato de o Irã cair nas mãos dos soviéticos, Truman vetou a ideia de ação militar contra o Irã e era antipático com a idéia de um golpe. A CIA nunca havia derrubado um governo, teria dito aos britânicos e não queria estabelecer um precedente aqui. Truman conhecera Mossadegh quando visitou Washington em 1951 - Mossadegh havia sido nomeado Homem do Ano da revista Time naquele ano - e não era antipático com o movimento nacionalista que ele liderou no Irã ${ }^{10}$.
\end{abstract}

Naquela época, o presidente americano, era o democrata Harry Truman. Este procurou solucionar a questão através de um acordo. Truman não desejava que se travasse um conflito maior entre os Estados, e não apoiava as aspirações de realizar uma invasão armada para retomar o controle da companhia de petróleo, ou de organizar um golpe contra Mossadeq (Kinzer, 2010: 117). O presidente tentou apaziguar este conflito e até recebeu Mossadeq na tentativa de celebrar um acordo, mas tanto este quanto os agentes britânicos foram inflexíveis.

Enquanto Mossadeq acusava a AIOC de causar toda a miséria do seu país, os britânicos alegavam que o petróleo iraniano os pertencia, nas palavras do subsecretário do Ministério do Combustível, Sir Donald Fergusson: "Foram os ingleses que extraíram o petróleo, que construíram a refinaria e que desenvolveram mercados para o petróleo persa em trinta ou quarenta países (...) e nada disso teria sido feito pelo governo ou pelo povo persa" (Kinzer 2010: 107).

Essa fala retrata o caráter orientalista engendrado. Os ingleses acreditavam que por terem construído a refinaria de petróleo e desenvolvido mercados para esse insumo, o petróleo lhes pertencia. Acreditavam que os iranianos não teriam a capacidade de fazê-lo por serem inferiores e terem menos capital e conhecimento. Todavia, o que Fergusson e a maioria dos orientalistas não levavam em consideração era toda a história de dependência que existia no Irã mesmo antes da petrolífera ter sido criada. A argumentação dos iranianos se dava pela Inglaterra só ter tido a capacidade para desenvolver tecnologia de extração e venda de petróleo por conta da história anterior (colonialismo) que este país desenvolvia no mundo. Por isso, utiliza-se aqui a Teoria Pós-Colonial, pois entende-se que não existe um fato singular que seja histórico, sendo necessário, portanto, analisar as raízes históricas

\footnotetext{
9 Fonte: Library of Congress Country Studies. http://memory.loc.gov/cgi-bin/query/r?frd/cstdy:@ field(DOCID+ir0025)

${ }^{10}$ Fonte: https: <//www.cia.gov/library/center-for-the-study-of-intelligence/csi-publications/books-andmonographs/agency-and-the-hill/12-The\%20Agency\%20and\%20the\%20Hill_Part2-Chapter9.pdf>.
} 
engendradas nas trajetórias dos países para compreender as relações de subordinação e dependência (ALVES, 2019).

Said faz alusão a como o Orientalismo se faz presente nas relações entre ocidentais e orientais, apresentando um argumento simplista, mas que engloba todo o pensamento orientalista a respeito dessa relação de poder que se impõe entre estas culturas. Nas palavras do autor:

Quando reduzimos à sua forma mais simples, o argumento era claro, era preciso, era fácil de compreender. Há ocidentais, e há orientais. Os primeiros dominam; os últimos devem ser dominados, o que geralmente significa ter suas terras ocupadas, seus assuntos internos rigidamente controlados, seu sangue e seu tesouro colocados à disposição de uma ou outra potência ocidental (Said, 2007: 68).

O governo britânico, para pressionar o norte-americano, alegou que grande parte da confusão estabelecida entre eles devia-se pela postura dos Estados Unidos. Isso foi dito por conta do episódio em que os norte-americanos aceitaram dividir os lucros da Arabian-American Oil Company em 50\% com os sauditas. Segundo os britânicos, caso os norte-americanos não tivessem dividido os lucros do petróleo em $50 \%$ com o proprietário da terra (Arábia Saudita) e 50\% com o dono da petrolífera (Estados Unidos), esse conflito entre Irã e Inglaterra não teria precedentes para ocorrer (Kinzer, 2010: 109).

Kermit Roosevelt era neto do ex-presidente dos Estados Unidos, Theodore Roosevelt. Segundo Kinzer (2010), Kermit Roosevelt viu na proibição da permanência dos ingleses no Irã uma oportunidade para o seu país, e se encaminhou para o Irã, uma vez que seus contatos britânicos ainda se encontravam ativos. Depois da visita ao Oriente Médio, voltou para o os Estados Unidos, mas antes fez escala em Londres, onde ele mesmo teria alertado os ingleses de que seria mais fácil se a negociação do golpe não fosse feita com o presidente Truman (Kinzer, 2010: 170).

Os ingleses, impacientes com a demora de Truman, tiveram as esperanças renovadas com a aproximação das eleições presidenciais americanas. Nutriam esperanças de alcançar seus objetivos caso Dwight Eisenhower, um republicano conservador, ganhasse as eleições. Eisenhower, certamente, seria mais facilmente convencido (Kinzer, 2010: 171).

Essa aposta se baseava, principalmente, no fato do Secretário de Estado deste governo ser John Foster Dulles, sócio sênior na Sullivan and Cromwell, um escritório de advocacia que representava a maioria das empresas petrolíferas norte-americanas (Polk, 2009: 179). Portanto, imaginava-se que este não fosse a favor da nacionalização, porque isso poderia gerar demandas por nacionalizações nas petrolíferas norte-americanas (Elm, 1992: 276).

Os britânicos decidiram mudar a estratégia de convencimento com Eisenhower. Utilizaram-se do argumento anticomunista para ganhar não somente o apoio do presidente como de todo o seu comitê e de alguns agentes da CIA (ELM, 1992: 293-296). Segundo o coronel do Serviço Secreto Britânico, C.M. Woodhouse: "Não desejando ser acusado de tentar usar os americanos para tirar castanhas britânicas do fogo, decidi enfatizar a ameaça 
comunista ao Irã, em vez da necessidade de recuperar o controle da indústria petrolífera" (Polk, 2009: 179, tradução nossa).

De fato, esse medo da expansão do comunismo com uma possível conversão do Irã ao regime parece ter pesado na decisão norte-americana (Elm, 1992: 276). Os britânicos alegavam que Mossadeq não iria suportar se o Tudeh realizasse um golpe com o apoio da União Soviética, o que faria com que o Irã e todo o seu petróleo fosse transferido para o controle comunista (Kinzer, 2010: 172). Embora essa apreensão do comunismo tenha sido motor propulsor dos norte-americanos para realizar a Operação Ajax ${ }^{11}$, mais tarde o próprio viabilizador da operação (Roosevelt) admitiu que o comunismo não era a preocupação da Inglaterra, mas sim a AIOC, como ilustrado por ele na passagem a seguir:

A proposta original para o AJAX (ou TP-Ajax, ambos usados como palavras de código para o golpe) veio da British Intelligence depois que todos os esforços para convencer Mossadeq a reverter sua nacionalização da Companhia de Petróleo Anglo-Iraniana (AIOC) falharam. A motivação britânica era simplesmente recuperar a concessão de petróleo da AIOC (Polk, 2009: 179, tradução nossa).

Esses depoimentos são de suma importância, pois revelam, em conformidade com a teoria da securitização, como o Irã foi transformado numa ameaça. Como destacado, a priori os Estados Unidos não estavam dispostos a interferir no Estado iraniano por conta da nacionalização do seu petróleo. Entretanto, quando a Inglaterra muda o discurso alegando que se tratava de uma potencial ameaça comunista, cria-se uma esfera de instabilidade que muda a postura norte-americana.

Tendo em vista que os Estados Unidos realizavam acordos petrolíferos menos desiguais com as nações detentoras do petróleo, estes pareciam perceber a exploração dos ingleses sobre o Irã. Todavia, quando a narrativa a respeito da ameaça vigente é modificada, e passa a ser a ameaça de um governo comunista no Oriente Médio, o presidente Eisenhower revê a posição norte-americana no conflito. Esse fato é relevante uma vez que percebemos como a questão da narrativa é primordial para convencer os atores a adotar determinadas posturas distintas diante de um mesmo cenário.

Mesmo durante a administração de Eisenhower, Mossadeq parecia acreditar que os norte-americanos seriam capazes de ajudar a solucionar o problema iraniano. Essa crença foi algumas vezes ratificada pelo próprio presidente norte-americano:

Espero que você aceite minhas garantias de que não comprometi de forma alguma nossa posição de imparcialidade nesse assunto (a disputa pelo petróleo) e que nenhum indivíduo tentou me prejudicar no assunto. Isso me leva a observar

\footnotetext{
${ }^{11}$ A Operação Ajax foi um plano articulado pelos Estados Unidos junto aos ingleses para depor o primeiroministro Muhammad Mossadeq, devido a este ter nacionalizado a petrolífera inglesa que extraia e vendia o petróleo iraniano. Segunda a CIA, a operação foi transmitida pela Inglaterra para o presidente Eisenhower para que este intervisse no Irã a fim de não permitir que esse acabasse se aliando aos comunistas. Os próprios documentos oficiais da CIA indicam que para saber maiores detalhes a respeito de como se sucedeu a Operação TPJAX deve-se ler o livro que temos abordado durante esta dissertação, de Stephen Kinzer. Fonte: <https://www.cia.gov/library/center-for-the-study-of-intelligence/csi-publications/booksand-monographs/agency-and-the-hill/12The\%20Agency\%20and\%20the\%20Hill_Part2-Chapter9.pdf>.
} 
que espero que nossos relacionamentos futuros sejam completamente livres de qualquer suspeita, mas, pelo contrário, caracterizados por confiança e confiança inspirados em franqueza e amizade (Polk, 2009: 180, tradução nossa).

Mossadeq envia uma carta ao Lord Henderson, que trabalhava no Ministério das Relações Exteriores, indagando que, se os Estados Unidos não pretendiam ajudar o Irã comprando seu petróleo, ou lhes emprestando dinheiro que pudesse ser convertido em petróleo. Na carta, afirma que venderia o insumo aos Estados Unidos com $40 \%$ de desconto (Elm, 1992: 283). Mas Henderson respondeu a Mossadeq sugerindo que ele deveria aceitar as condições propostas pela Inglaterra a respeito da AIOC. Este parece ter sido o primeiro momento que Mossadeq percebe que os Estados Unidos não estavam necessariamente ao lado do Irã (Elm, 1992: 284). Vale lembrar que, por mais de um século, os iranianos haviam entendido os Estados Unidos como uma nação à qual eles podiam recorrer quando ameaçados pelos russos ou pelos ingleses.

Eisenhower, assim como Truman, não eram adeptos do boicote à Mossadeq. Contudo, depois de ser aconselhado por seus aliados de que essa seria a melhor forma de lidar com a possível perda do território para a União Soviética, resolveu negligenciá-lo e, dessa forma, permitiu que o golpe acontecesse. É preciso advertir que antes mesmo do presidente americano possibilitar a realização da Operação Ajax, também conhecida pela alcunha "Operação Pontapé", esta já estava sendo articulada pela CIA junto ao Serviço Secreto de Inteligência Inglês e o Departamento do Estado Inglês (Kinzer, 2010: 178-180; Wilber, 2012: 13).

0 trecho de um relatório da CIA sobre a Operação é bastante esclarecedor:

\begin{abstract}
Quando o Eisenhower assumiu o cargo, no entanto, os britânicos encontraram um ouvido mais compreensivo. A essa altura, havia uma crescente insatisfação com Mossadegh dentro do Irã entre aqueles que desejavam devolver o controle do país ao monarca. Além disso, seu relacionamento com a União Soviética parecia estar se aproximando, e o partido comunista Tudeh ganhou força e se alinhara amplamente com Mossadegh. A DCI Dulles e outros alertaram Eisenhower, na primavera de 1953, que o governo iraniano estava em risco de colapso, potencialmente dando aos soviéticos a oportunidade de assumir o controle. Com base nessas preocupações, Eisenhower aprovou, com aparente relutância, um esforço secreto para derrubar Mossadegh ${ }^{12}$ (Tradução nossa).
\end{abstract}

Ao mesmo tempo em que Estados Unidos e Inglaterra estudavam as maneiras de realizar a Operação Ajax no Irã, os agentes iranianos pagos pelo governo inglês tornavam o Irã um caos. E estes eram inúmeros, dentre os quais: políticos, bazaar (classe média comerciante), mullahs (líderes e pessoas instruídas na religião islâmica) e gangues. 0 governo inglês financiava grupos a fim de instaurar uma esfera de instabilidade e, dessa maneira, tornar mais simples a deposição do líder (Kinzer, 2010: 172-180).

É importante destacar o que Ervand Abrahamian (1983) discorre no seu livro Iran Between Two Revolutions, de que Mossadeq também estava fragilizado no Irã para sofrer

\footnotetext{
${ }^{12}$ Fonte: https://www.cia.gov/library/center-for-the-study-of-intelligence/csi-publications/books-andmonographs/agency-and-the-hill/12-The\%20Agency\%20and\%20the\%20Hill_Part2-Chapter9.pdf.
} 
o golpe. Isso porque durante o seu governo, tomou determinados posicionamentos que não agradaram a ala religiosa do Irã, como quando ofereceu cargos nos ministérios da agricultura, do transporte, da justiça e do interior para o partido secular e o ministério da educação a um professor universitário apoiador do Tudeh. Seus ministros fizeram propostas de estatizar também as companhias de ônibus e de telecomunicações e diminuir os preços da comida, o que foi mal visto pelo baazar e gerou protestos. Abol-Ghasem Kashani publicou à época que o "Islã protegia a propriedade privada e proibia expropriações" (apud Abrahamian, Ervand, 1983).

As propostas de reformas progressistas dos ministros de Mossadeq ajudavam no seu enfraquecimento junto às elites políticas e religiosas. Propostas a respeito da venda de bebidas alcoólicas foram feitas (para arrecadar impostos na crise que o país enfrentava) e também do voto se estender às mulheres, uma vez que a constituição tratava todos os cidadãos como iguais. Isso permitiu que os ulemás protestassem junto à estudantes de teologia de que "a lei religiosa indubitavelmente limita o direito ao voto aos homens" (Nariman, 1952 apud Abrahamian, 1983) e de que "o governo deveria prevenir as mulheres de votar para que ficassem em casa e pudessem se dedicar exclusivamente a sua verdadeira função: criar os filhos" (Kashani, 1952 Apud Abrahamian, 1983: 276). E foi nesse contexto de insatisfação, que existia também entre a ala mais conservadora, que Fazlollah Zahedi encontrou oportunidade para realizar o golpe.

A Operação Ajax entrou em andamento quando Churchill e Eisenhower chegaram a um acordo. 0 trabalho foi realizado pela CIA e o Serviço Secreto Inglês através do investimento de dólares. Para substituir Mossadeq, os Estados Unidos e a Inglaterra já haviam escolhido o general Fazlollah Zahedi (Wilber, 2012: 15; Abrahamian, 1983: 279).

Muitos agentes invisíveis manipulariam a opinião pública contra o primeiro-ministro (Wilber, 2012: 15), alegando que ele e a Frente Nacional eram agentes comunistas que pretendiam destruir o Islam (Polk, 2009: 180; Elm, 1992: 305). Enquanto isso, outros agentes atacariam líderes religiosos a fim de fazer parecer que era Mossadeq quem estaria realizando essas ofensivas (Kinzer, 2010: 184). Ao mesmo tempo, Zahedi pagaria oficiais do exército e políticos do Majlis para lhe apoiar no golpe. Por fim, no dia do golpe aconteceria uma passeata (financiada pela CIA) solicitando a deposição de Mossadeq, e nesse momento os Majlis votariam pela sua substituição. Caso tentasse resistir, Zahedi estaria com o exército, que prenderia ele e todos que estivessem ao seu lado. Os militares tomariam os principais órgãos de Teerã como o Banco Nacional, delegacias de polícia, entre outros.

A maioria dos agentes da CIA chegaram a Teerã em julho de 1953. E em agosto tentaram pela primeira vez realizar o golpe. Contudo, essa tentativa foi fracassada (Kinzer, 2010: 187). Roosevelt acreditava que a um golpe célere seria eficaz e tentou novamente junto aos agentes infiltrados.

Ainda em agosto muitas manifestações foram feitas contra Mossadeq e a favor do Xá, como destacado no trecho a seguir do relatório da CIA a respeito da operação: “Usando uma 
rede de contatos deixados para trás pela inteligência britânica e pelos ativos da Agência, ele montou uma intensa campanha de propaganda contra Mossadeq, estimulando manifestações e protestos em todo o país"13 (Tradução nossa). Junto a isso, notícias contra o primeiro-ministro também eram difundidas por jornais e rádios. Mossadeq não os censurava e, assim, era cada vez mais atacado por notícias em grande medida manipuladas pela CIA, conforme alega Richard Cottam, propagandista de Washington. 0 referido chegou a dar declarações, anos após o golpe, afirmando acreditar que 4/5 dos jornais iranianos da época haviam sido manipulados pela CIA. Segundo Cottam: "Todo artigo que eu escrevia saía publicado quase imediatamente, no dia seguinte, na imprensa iraniana. Eles eram concebidos para mostrar Mossadeq como colaborador comunista e fanático" (Kinzer, 2010: 22-23; Wilber, 2012: 16-37; Kinch, 2016: 43).

Uma das estratégias elaboradas para realização do golpe foram os firmans, isto é, decretos assinados pelo Xá Muhammad Reza Pahlavi, que destituíam o primeiro-ministro (Wilber, 2012: 15-33; Elm, 1992: 302). O Xá receou ${ }^{14}$ em assiná-los por medo das consequências que o esperariam caso o golpe fracassasse, e foi precisamente tal temor que fez com que, após assinar esses documentos, o monarca tenha fugido para Bagdá e posteriormente se exilado em Roma.

Quando a primeira tentativa do golpe fracassou, Mossadeq foi às rádios para anunciar que havia escapado e que, desse modo, continuava sendo o primeiro-ministro do Irã. Também alegou que o golpe fora elaborado pelo Xá e por estrangeiros (até então Mossadeq não tinha conhecimento do envolvimento norte-americano). Depois desse pronunciamento, as massas satisfeitas ocuparam as ruas da cidade aos gritos de "Mossadeq venceu!" e "Vitória da Nação!" (Kinzer, 2010: 32).

Roosevelt voltou a articular o novo golpe, e, por isso, uma das primeiras providências que tomou foi a de persuadir a imprensa a informar que aquilo não fora um golpe contra Mossadeq, como o primeiro-ministro havia relatado. Tratava-se, conforme veiculado na mídia no dia seguinte, da tentativa de Mossadeq de destituir o Xá, mas oficiais o haviam impedido.

Roosevelt procurou mais oficiais do exército e passou a contratar também sujeitos que se dissessem comunistas e partidários de Mossadeq, e que estivessem dispostos a causar confusões nas ruas, quebrando tudo que encontrassem, provocando brigas etc. (Abrahamian, 1983: 279). No parágrafo ilustrado no documento oficial da CIA, a agência deixa claro como as manifestações que ocorriam no Irã eram contratadas por Roosevelt a fim de deslegitimar o governo de Mossadeq:

\footnotetext{
${ }^{13}$ Fonte: <https://www.cia.gov/library/center-for-the-study-of-intelligence/csi-publications/books-andmonographs/agency-and-the-hill/12-The\%20Agency\%20and\%20the\%20Hill_Part2-Chapter9.pdf>.

${ }^{14}$ Foi necessário que a irmã do Xá, a princesa Ashraf Pahlavi, saísse da Europa e fosse até o irã convencê-lo a destituir Mossadeq do cargo. (Wilber, 2012: 15-30). Os agentes britânicos e norte-americanos ofereceram dinheiro e outros presentes para que a princesa aceitasse convencer seu irmão a destituir Mossadeq (Filliu, 2012: 95).
} 
Roosevelt tentou novamente alguns dias depois, no entanto, primeiro organizando violentas manifestações "falsas" contra a monarquia, que de fato se juntaram a membros do partido Tudeh; depois organizando demonstrações de "reação" em apoio ao Xá. Enquanto isso acontecia, as unidades militares iranianas, a polícia e os membros das tribos rurais sob o controle de Roosevelt foram capazes de superar as limitadas forças militares que Mossadegh poderia reunir ${ }^{15}$ (Tradução nossa).

As manifestações ocorreram, e Mossadeq a princípio não as reprimiu. A instabilidade foi tamanha que os cidadãos comuns começaram a acreditar que seu país se encontrava desordenado e que, por isso, precisava de alguém dotado de maior autoridade para comandá-lo.

Ao mesmo tempo, o embaixador norte-americano do Irã, Henderson, marcou um encontro com Mossadeq e disse que muitos de seus conterrâneos que moravam no Irã recebiam ligações grosseiras de iranianos incitando-os a voltarem para a casa. Esse argumento era falso, Roosevelt o havia planejado. Mossadeq, após este relato ordenou que a polícia reprimisse a desordem da cidade (Kinzer, 2010: 197).

Roosevelt convocou novos sujeitos para depor o governo. Os partidários de Mossadeq não saíram às ruas nesse dia, conforme haviam se comprometido. Os infiltrados gritavam: “Vida longa ao Xá!" e "Morte a Mossadeq!", enquanto incendiavam edifícios do governo e jornais de Teerã (Elm, 1992: 307).

Algumas centenas de pessoas morreram nessa manifestação. Nas palavras de Cottam: "A massa popular que entrou no norte de Teerã e foi decisiva para a derrubada do governo era uma turba de mercenários. Essa massa não era movida por nenhuma ideologia, era paga com dólares americanos" (apud Kinzer, 2010: 201; Elm, 1992: 307).

Uma estação de rádio foi tomada pelos agentes de Roosevelt, que anunciaram a queda do governo de Mossadeq e o retorno em breve do Xá. Mas as afirmações não eram verdadeiras, visto que os protestantes ainda não haviam chegado à casa de Mossadeq. Enquanto os manifestantes para lá se encaminhavam, o general Zahedi foi levado a uma rádio da cidade, onde declarou ser o novo primeiro-ministro e fez algumas promessas de melhorias para o Irã. Também foram tomadas estações de correio, que enviavam notícias a todo país sobre a suposta deposição de Mossadeq, ainda que esta não tivesse sido realizada oficialmente até aquele momento (Kinzer, 2010: 204-205).

O Xá afirmou a veracidade dos fatos e alegou ter nomeado o general Zahedi. Mossadeq permaneceu em casa até que foi persuadido pelos seus auxiliares a pular os muros e fugir. Nesta ocasião, oficiais e políticos pró-Mossadeq foram presos (Wilber, 2012: 18; Elm, 1992: 308).

Roosevelt, seus agentes, Zahedi e seu filho comemoravam a vitória da Operação Ajax e comunicaram o embaixador norte-americano Henderson do sucesso da mesma. Quando encontraram Zahedi, Roosevelt fez um breve discurso para a multidão e depois se retirou

\footnotetext{
${ }^{15}$ Fonte: https://www.cia.gov/library/center-for-the-study-of-intelligence/csi-publications/books-andmonographs/agency-and-the-hill/12-The\%20Agency\%20and\%20the\%20Hill_Part2-Chapter9.pdf.
} 
do local (Kinzer, 2010: 208). Estima-se que cerca de trezentas pessoas tenham morrido durante o golpe.

Na manhã seguinte, jornais de todo o mundo divulgavam a queda do governo de Mossadeq. Assim que o general Zahedi se tornou primeiro-ministro foram reprimidas todas as manifestações, substituídos alguns governantes que eram parceiros de Mossadeq e declarado na rádio que Mossadeq deveria se render. Por fim, Zahedi enviou um telegrama ao Xá afirmando que poderia voltar ao Irã.

Mossadeq rendeu-se à Zahedi junto a alguns de seus apoiadores. No mesmo dia, o Xá retornou ao Irã. (Kinzer, 2010: 213). Segundo Hiro, o golpe "destruiu qualquer chance do Irã evoluir como uma democracia ao estilo ocidental" (Hiro, Dilip, 1985: 36, tradução nossa).

Quando o Xá retorna ao Irã, fica claro que ele estava articulando o golpe e, a partir de então, os iranianos passaram a perceber o Xá como um "fantoche da América" (Polk, 2009: 182; Abrahamian, 1983: 280). Desde então teve início entre diferentes grupos, o sentimento antiamericano no Irã. Alguns porque entendiam a volta do Xá, por meio da Operação Ajax, a CIA e os Estados Unidos destituíram o Irã da possibilidade de lograr um país democrático e economicamente independente, capazes de reger seus próprios assuntos, sem a interferência estrangeira, que seriam os setores progressistas (Elm, 1992: 309). Como destacado por Alethia Cook e Jalil Roshandel, “O papel americano no golpe de 1953 será sempre visto pelos iranianos como evidência concreta das intenções imperialistas americanas em relação ao Oriente Médio em geral e Irã em particular" (Cook, Alethia \& Roshandel, Jalil, 2009: 16, tradução nossa). Enquanto a ala religiosa e conservadora, apesar de insatisfeita com Mossadeq, não almejavam a volta do Xá, porque entendiam que esse trazia os valores estrangeiros para o país, que era um traidor do Islã.

Edward Said faz uma afirmação sobre as políticas intervencionistas que os Estados Unidos realizam pelo globo, cujo enfoque no Oriente Médio que se alinha ao pensamento deste trabalho. Da maneira como este Estado se comporta, influenciando nas decisões internas dos demais países, seja por golpes, por embargos ou por pressões externas, acaba por criar uma atmosfera não apenas de liderança na chamada comunidade internacional, mas muitas vezes de um interventor capaz de decidir o futuro de determinados países a seu bel prazer. Isso faz com que muitos passem a encarar os norte-americanos como uma espécie de inimigo de suas nações. Nas palavras de Said:

A coisa toda tem sido uma política totalmente desastrosa e fútil. A ironia disso. 0 poder, a riqueza e distância dos Estados Unidos é tal que a maioria das pessoas não tem noção do estrago que tem sido causado em seu nome e, pior, do ódio que se propagou contra os Estados Unidos no Oriente Médio e no mundo islâmico pelo único motivo de garantir a contínua predominância de uma pequena maioria, cujos interesses estão ligados a essa política ridícula e desumana (Said, 2003: 98). 
Muitos são os autores que fazem conexão entre o golpe de estado que ocorreu no Irã em 1953 com a Revolução Iraniana de 1979, como Limbert, Green, Costa, Kinch, Cook, Roshandel, entre outros. Isso se deve ao fato, anteriormente salientado, de que o sentimento antiamericano não parecia existir até que os iranianos percebessem que o Xá estava respaldado pelos norte-americanos, e não apenas pelos britânicos, como esperado.

\begin{abstract}
Futuramente, Christopher Woodhouse - agente britânico que auxiliou no Golpe a Mossadegh — daria uma entrevista a Robert Fisk (2007) reconhecendo que a atuação estadunidense e britânica no Irã teria aberto as portas para os acontecimentos que ocorreriam em 1978. Um risco que foi inebriado pela lógica da Guerra Fria e pela visão defasada de "potência colonizadora" dos britânicos, a qual não abriu mão de seu lucro com a exploração do petróleo e propiciou o surgimento da onda nacionalista iraniana (Costa, 2013: 123).
\end{abstract}

E esse é justamente o argumento que esse trabalho utiliza para aventar que o momento de ruptura nas relações entre Irã e Estados Unidos se deu em tempos e espaços distintos. Para muitos iranianos, ocorreu em 1953 com o golpe de Estado levado a cabo contra o primeiro-ministro Mossadeq. Para os Estados Unidos, por sua vez, essa relação só será rompida com o sequestro da embaixada americana, durante a Revolução Iraniana de 1979.

Outro fator interessante é como a CIA apresenta o golpe no Irã em seu relatório oficial. Os jornais à época, como o New York Times, relataram o ocorrido no Irã como manifestações legítimas realizadas por admiradores do Xá contra Mossadeq. Como destacado no trecho a seguir:

\begin{abstract}
O New York Times retratou o golpe como um esforço dos iranianos leais ao Xá para devolvê-lo ao poder. 0 artigo da CIA não foi mencionado. Em outro artigo publicado no mesmo dia, o Times informou que o jornal soviético Pravda havia acusado os agentes americanos que operavam no Irã de projetar o golpe. Isso poderia muito bem ter motivado a agência. superintendentes no Congresso para acompanhar DCI Dulles, mas não há evidências de que eles o fizeram. Com toda a probabilidade, a acusação, proveniente dos soviéticos, não era vista como credível. Não houve histórias de acompanhamento que apareceram imediatamente na imprensa americana, nem houve investigações formais do congresso ${ }^{16}$ (New York Times, tradução nossa).
\end{abstract}

Esse trecho apresenta como as mídias têm um papel fundamental na legitimação de determinadas práticas. Ao declarar que os manifestantes comprados pela CIA eram na verdade cidadãos iranianos pró-regime do Xá, a imprensa torna legítimo o golpe de Estado no Irã, e com isso tenta convencer a audiência de que foi bom para aquela população que o Xá volte ao poder.

\title{
A VOLTA DO XÁ
}

Quando Pahlavi retornou, transformou o país numa ditadura monárquica, onde o parlamento deixou de existir como um poder efetivo e qualquer indivíduo que se opusesse

\footnotetext{
${ }^{16}$ Fonte: New York Times "Royalists Oust Mossadegh: Army Sizes Helm”.
} 
às suas políticas era considerado subversivo e deveria ser exilado, aprisionado ou morto (Polk, 2009: 184).

Mossadeq foi a julgamento, acusado de traição por não ter cumprido a demissão que o Xá havia ordenado através dos firmans, e por incitar a sociedade à luta armada. Em resposta às acusações alegou: "Meu único crime foi ter nacionalizado a indústria iraniana do petróleo e eliminado desta pátria a rede colonialista e a influência política e econômica do maior império da Terra" (Kinzer, 2010: 214). 0 Xá decidiu que Mossadeq deveria ser detido por três anos, e ao fim deste período seria mantido em prisão domiciliar perpétua. Aos aliados de Mossadeq, como os membros do Tudeh e da Força Nacional as penas aplicadas também foram duras, muitos foram presos de maneira perpétua, torturados ou executados. A ideia de Pahlavi era de eliminar a oposição do seu governo (Abrahamian, 1983: 280). Em 5 de outubro de 1967, Mossadeq falece por conta de um câncer na garganta, e não foi permitido que houvesse um funeral público, nem manifestações de luto popular (Kinzer, 2010: 216).

A AIOC não poderia continuar funcionando nos moldes anteriores à posse de Mossadeq pela má reputação e pelos dólares norte-americanos investidos no golpe. Desta maneira, a AIOC ficou com $40 \%$ do mercado petrolífero iraniano e vendeu, por um bilhão de dólares, os outros $60 \%$ do mercado para cinco empresas norte-americanas, uma holandesa e uma francesa (Polk, 2009: 182). 0 nome dado por Mossadeq à empresa, Companhia Nacional Iraniana de Petróleo, foi mantido para preservar uma imagem ilusória de nacionalização. A petrolífera passou a dividir os lucros em 50\% com o Irã, embora nunca tenha aberto seus livros para conferência da veracidade das informações (Coggiola, 2008: 42).

Uma das políticas do novo governo do Xá foi a criação, em 1957, da Savak (polícia política). Esta foi a responsável pela tortura e pela morte de muitos cidadãos, políticos e, até mesmo, mullahs no Irã (Gordon, 1987: 15-16). Tal polícia foi treinada pela CIA e pelo Mossad (serviço secreto de Israel).

Nos anos que se seguiram ao golpe, o Xá pretendia manter os planos de seu pai de tornar o Irã uma das cinco potências mundiais. Com tal objetivo, passou a investir em armamentos, os quais eram importados, principalmente, dos Estados Unidos, da União Soviética e de outros países. Entre 1972 e 1978, importou 20 bilhões de dólares em compras militares só dos Estados Unidos. Segundo Polk, os Estados Unidos ajudaram o Xá a acreditar que se investisse em armamento, poderia chegar a superar as capacidades militares da União Soviética. Também o incitaram a investir num programa de armas nucleares, realizando um acordo sobre tal programa em 5 de março de 1957 (Polk, 2009: 187).

Esse acordo demonstra o que se busca ressaltar nesse trabalho, a saber: como um ato isolado pode ser interpretado de maneiras distintas dependendo de quando e de quem o interpreta. Enquanto em 1957 os Estados Unidos não apenas consentiram como apoiaram 
a criação de um programa nuclear ${ }^{17}$ iraniano, com o advento da República Islâmica, em 1979, o apreço do Irã dá lugar a uma suposta ameaça não apenas para os Estados Unidos, mas para toda a chamada comunidade internacional.

Vale lembrar que, com o advento da Guerra Fria, Estados Unidos e União Soviética procuraram manter a relações amigáveis com as demais regiões. Neste contexto, foi criado, em 1955, o Pacto de Bagdá (Polk, 2009: 183), um acordo sobre a segurança do Oriente Médio, assinado pela Inglaterra, Turquia, Irã, Iraque, Paquistão e Estados Unidos. 0 Pacto tratava-se de uma colaboração, na qual eles instalariam bases militares para proteger o petróleo dessa região (Weil, 2007: 161).

Este pacto foi visto, contudo, como um retrocesso por alguns países, uma vez que restabelecia o domínio das potências ocidentais sobre os países signatários. Muitos Estados, como a União Soviética, interpretaram esse acordo como uma tentativa por parte das potências estrangeiras de influenciar no equilíbrio da região (Lewis, 1996: 323). Os soviéticos foram contrários à celebração deste acordo, alegando que em 1927 o Irã e a União Soviética haviam feito um acordo por meio do qual estabeleciam o compromisso de que nenhum deles iria aderir políticas que comprometessem sua soberania e integridade. Contudo, os apelos da União Soviética não foram capazes de impedir o pacto.

Na década de 1960, começam a surgir manifestações expressivas contra o regime autoritário de Pahlavi. Uma delas ocorreu por conta da fraude nas eleições dos Majlis. Após as reivindicações, houve uma greve que foi imediatamente contida pela Savak. Foi a partir deste episódio que o Xá decidiu iniciar um de seus projetos mais ambiciosos, a Revolução Branca, também conhecida como "Revolução Xá-povo". Segundo o monarca, a Revolução envolvia a adoção de medidas modernizadoras. Todavia, na prática, segundo Polk e Coggiola, os pobres se tornaram ainda mais miseráveis enquanto os ricos enriqueciam mais a cada dia (Polk, 2009: 183-184). Seu objetivo era o de tornar o Irã uma das grandes potências mundiais, mas também torná-lo um país laico e capitalista.

Numa carta enviada aos Estados Unidos pelo professor norte-americano, T. Cuyler Young, alertava como o regime do Xá era considerado como uma ferramenta de corrupção dos interesses estrangeiros, principalmente, anglo-americanos (Polk, 2009: 184).

A plataforma da Revolução Branca continha as seguintes metas: nacionalização das florestas, vendas de ações das indústrias iranianas para empresas privadas estrangeiras, criações de exércitos do saber, de higiene, do desenvolvimento e da reconstrução (Meihy, Murilo, 2007: 36). Além disso, previa reformas na lei, participação dos operários das indústrias nos lucros das empresas e a implantação de casas de equidade no interior do país (Meihy, 2007: 36). O Xá, através da “Revolução Xá-povo”, procurou concentrar o poder e retirá-lo dos Majlis, por possuir “caráter divino”. Nas palavras de Pahlavi:

\footnotetext{
${ }^{17}$ No final deste capítulo encontra-se o folder que fazia a propaganda a respeito de como energia nuclear era benéfica e que o Xá também estava investindo na mesma.
} 


\begin{abstract}
Christensen, o orientalista dinamarquês, afirmou, com razão, que um verdadeiro rei no Irã não é tanto o chefe político da nação como professor e líder. Ele não é apenas uma pessoa que constrói estradas, pontes, represas e canais, mas alguém que os conduz em espírito, pensamento e coração. Isso possivelmente pode explicar por que um monarca, se ele tem toda a confiança do povo e usa sua grande influência, pode conseguir tanto sem ter que confiar em medidas totalitárias ou esperar que processos evolutivos lentos atinjam seus objetivos (Pahlavi, 1967: 2 apud Meihy, 2007).
\end{abstract}

Murilo Meihy aponta para a importância desta frase do Xá, por ele fazer um discurso tomando a ciência ocidental como uma referência. Isso é de suma relevância também para a argumentação, visto que é num acadêmico ocidental (Emanuel Christesen) que o Xá busca argumentos para basear o seu discurso para o povo iraniano. Nas palavras de Meihy: "Se os ocidentais percebem o Irã a partir de determinados signos, o modelo de nação a ser reproduzido no país deve refletir a visão que a 'ciência ocidental' estabeleceu como característica da comunidade nacional" (Meihy, 2007: 37).

O Xá defendia em seus discursos da "Revolução Branca" um caráter liberal para a nova sociedade iraniana que se configuraria. Com isso, afastava a religião islâmica da ótica do Estado iraniano. Portanto, a "Revolução Branca" era uma reforma modernizadora, que visava aproximar o Estado iraniano dos valores ocidentais liberais e de iniciativa privada. Todavia, por estar envolto num discurso nacionalista, o Xá tentava passar a ideia de que não se tratava de uma importação de valores estrangeiros, mas sim, da exaltação de características iranianas por meio de sua revolução (Meihy, 2007: 40).

Apesar deste cenário adverso, a economia iraniana cresceu nesses anos, através da venda do petróleo do país. Convém notar, contudo, que o capital advindo de tal crescimento não foi transferido, via investimentos, para a população (Polk, 2009: 184).

Nesse mesmo período, o governo colocou em vigor leis que representaram enfrentamento ao Islamismo, como: lei que autorizava o voto feminino nas eleições, lei que flexibilizava os preceitos islâmicos e permitia que candidatos eleitos fizessem seus juramentos sobre quaisquer livros sagrados e, não apenas, sobre o Alcorão. Para os muçulmanos religiosos, estas leis constituíam uma afronta ao Islamismo e aos costumes da religião (Gordon, 1987: 42). Devido, em grande medida, a tais reformas religiosas, os ulemás e os mullahs se colocaram totalmente contra a Revolução Branca e, principalmente, contra a proclamada origem divina da liderança do Xá. Já os líderes políticos (e não religiosos) contrários às reformas do Xá, não partilhavam do mono partidarismo instaurado. Acusavam a política do Xá e da Savak, de violarem os direitos humanos e de serem medidas arbitrárias, oriundas de um regime ditatorial (Pazzinato, Alceu Luiz \& Senise, Maria helena Valente, 1994: 353).

Em setembro de 1960 foi oficialmente fundada a OPEP (Organização dos Países Exportadores de Petróleo). Os países que selaram a cooperação com a criação deste cartel numa reunião em Bagdá foram: Arábia Saudita, Irã, Iraque, Kuwait e Venezuela. Decidiram se agrupar porque, naquele ano, o cartel das empresas petrolíferas internacionais, mais 
conhecidas como as Sete Irmãs, tinha reduzido o preço do petróleo, o que prejudicava seus produtores. Com o passar dos anos, a dinâmica de decisões, que antes eram concentradas nas companhias ocidentais, passou a ser tomada pelos próprios produtores de petróleo, que passaram a decidir sobre os royalties, cotas de produção e lucro estimado.

Cerca de 25 bilhões de dólares por ano eram recebidos pelo governo do Irã com o aumento do preço do petróleo, segundo Coggiola. O Irã passou a usar grande parte deste capital para se militarizar e outra parte para o enriquecimento da elite iraniana. O Xá gastava milhões com festas enquanto a grande maioria da população sofria com a fome, o desemprego, o êxodo rural, a ausência de moradia e, principalmente, com a desigualdade social (Coggiola, 2008; Polk, 2009).

Com o aquecimento da economia iraniana por conta da alta do petróleo e a consequente alta do PIB iraniano (crescimento de 33,9\% em 1974 e 41,6\% em 1975, as indústrias do país cresceram e com elas também aumentou a camada social do proletariado iraniano que, mais tarde, foi a classe em grande medida responsável pela deposição do Xá. O Irã chegou a gastar $25 \%$ do seu PIB com a compra de equipamentos militares (Coggiola, 2008: 62-64).

É certo que algumas vezes o Xá, reconhecido pelos norte-americanos como adorador da tecnologia militar (Polk, 2009: 187), foi questionado pelos Estados Unidos acerca do tamanho do seu arsenal militar, dado o alegado perigo de que esse fosse roubado pelos comunistas (Coggiola, 2008: 60). Com o passar dos anos parecia óbvio que o monarca não importava armamento apenas para defender o Irã, mas sim para reprimir as revoltas da população iraniana. Pahlavi foi o único líder do Oriente Médio a não aderir ao embargo da venda de petróleo realizado pelos países árabes contra Israel.

O papel desempenhado pelos Estados Unidos é crucial para o retorno do governo de Pahlavi. Isso porque além do apoio ao golpe realizado pela CIA que permitiu que ele voltasse ao poder, como também porque o alinhamento de determinados países árabes, como é o caso do Irã, à Israel, apresentava para os cidadãos daquele país, como as políticas empregadas por ele muitas vezes se voltavam mais para benefícios e contratos selados com países estrangeiros do que abarcavam suas reivindicações locais.

A problematização de Said vai mais além e se aproxima de um dos grandes vetores desse trabalho, que é questionar os valores que os Estados Unidos e a dita comunidade internacional alegam ser tão essenciais para o sistema internacional. Valores como: democracia, direitos humanos, autodeterminação, entre outros, são propagados como soluções para os conflitos internacionais, todavia, apesar destes Estados defenderem tais valores, muitas vezes, como no caso de Israel, o que se pode perceber é uma ajuda desproporcional para um único Estado, um golpe a democracia como o realizado no Irã em 1953, entre outras muitas práticas políticas implementadas que em nada se assemelham aos valores propagados e ditos como universais (Said, 2003: 109). A impressão que muitas vezes perpassa no Oriente Médio, portanto, é que as práticas engendradas pelos norte-americanos 
estão mais atreladas aos seus próprios benefícios do que aos da comunidade internacional, como propagam em seus discursos internacionais.

\begin{abstract}
Acho que a maioria dos árabes e muçulmanos têm a impressão de que os Estados Unidos não têm realmente prestado muita atenção aos seus desejos, mas têm insistido em políticas para seu próprio bem, sem muitas explicações ou tentativas de, de certa forma, justifica-las. E acima de tudo, têm prosseguido com essas políticas que contradizem vários princípios que os Estados Unidos defendem: democracia, autodeterminação, liberdade de expressão, liberdade de assembleia, compromisso com o direito internacional (Said, 2003: 109).
\end{abstract}

Medidas modernizadoras, como a proibição do véu, eram percebidas como uma submissão aos interesses estrangeiros. Por isso, cresceu entre a população iraniana uma espécie de nacionalismo que era tangenciado para a veia religiosa islâmica dessa população. James Gelvin discorre a respeito desse "nacionalismo islâmico" no trabalho intitulado Modernity and its discontents: on the durability of nationalism in the Arab Middle East (1999). O autor acredita que esse nacionalismo teria sido criado devido ao encontro colonial, uma vez que os valores europeus agregados às questões políticas emancipatórias da região do Oriente Médio teriam gerado esse ativismo político na região (Gelvin, 1999: 81).

Assim, em contraste com - e frequentemente em resposta às - tentati-
vas feitas pelas elites ocidentais durante a primeira metade do século XX de
inventar tradições para inculcar valores não convencionais, os nacionalistas
populares adaptaram e recontextualizaram (nacionalizaram) os símbolos
comuns, incluindo símbolos que até então haviam aparecido em contextos
essencialmente religiosos ou comunitários. Entre eles estavam os apelos
ao martírio da jihad, a defesa do Islã e a unidade islâmica (Gelvin, 1999: 82,
tradução nossa).

Said, quando discorre a respeito dos ditos fanáticos religiosos e não dos cidadãos que são apenas muçulmanos, alega que, devido à postura estadunidense de violar diversas vezes a soberania do Oriente Médio e por esse Estado também falhar em relação à propensão dos direitos internacionais para com esses países, eles encontraram um ambiente propício para propagar ideias de uma dita cruzada contra os Estados Unidos. Se utilizariam das bandeiras de resistência e nacionalismo político islâmico para tangenciar essa luta para uma brigada sanguinária contra os Estados Unidos (Said, 2003: 109).

o que Said revela como mais peculiar é que esses mesmos sujeitos foram outrora apoiados pelo governo dos Estados Unidos quando lhes convinha. Tanto Saddam Hussein, Osama Bin Laden quanto o próprio Khomeini tiveram tentativas de fechamento de acordos e até mesmo apoios financeiros fornecidos quando o principal inimigo norte-americano era o comunismo. 

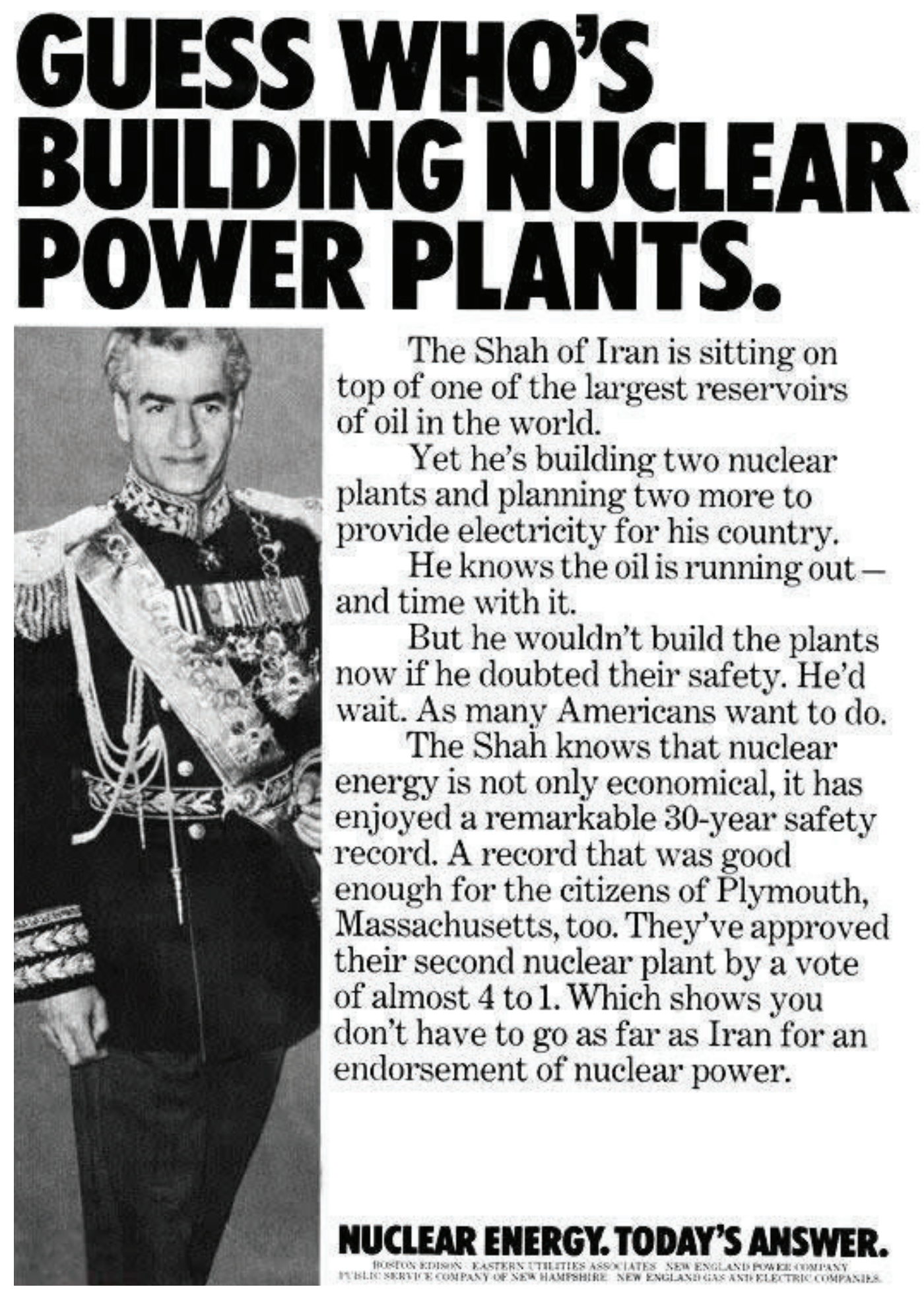

The Shah of Iran is sitting on top of one of the largest reservoirs of oil in the world.

Yet he's building two nuclear plants and planning two more to provide electricity for his country. He knows the oil is running outand time with it.

But he wouldn't build the plants now if he doubted their safety. He'd wait. As many Americans want to do. The Shah knows that nuclear energy is not only economical, it has enjoyed a remarkable 30 -year safety record. A record that was good enough for the citizens of Plymouth, Massachusetts, too. They've approved their second nuclear plant by a vote of almost 4 to 1 . Which shows you don't have to go as far as Iran for an endorsement of nuclear power.

\section{NUCLEAR ENERGY.TODAY'S ANSWER.}

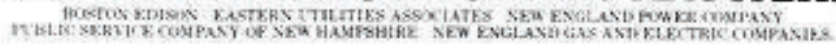

\section{CONSIDERAÇÕES FINAIS}

Este capítulo procurou, através dos acontecimentos históricos narrados e da perspectiva Pós-Colonial, demonstrar como a visão ocidental é limitada para a compreensão das relações entre o Ocidente e o Oriente.

As constantes intervenções que o território iraniano sofreu, principalmente por parte da Inglaterra e dos Estados Unidos, criaram uma esfera de repúdio em relação ao Ocidente. 
Consequentemente, as questões iranianas nunca estiveram totalmente separadas, isoladas, do Ocidente, mas, diferentemente, essas identidades parecem estar entrelaçadas e se constituíram mutuamente através dos múltiplos encontros históricos.

Foi necessário recuperar parte da história iraniana para entendermos as inúmeras intervenções estrangeiras no Irã e como as mesmas contribuíram para as escolhas políticas do país. Houve um esforço em salientar que escolhas políticas foram realizadas pelas potências em detrimento de regimes democráticos para a manutenção do monopólio do petróleo iraniano. Exemplo claro foi o golpe de 1953 articulado e financiado pela CIA.

O Irã, que desde tempos imemoriais tem sido alvo de invasores estrangeiros devido a uma geografia que o colocou a cavaleiro de algumas das mais importantes rotas de comércio do mundo e deitados sobre um oceano de petróleo, vem lutando para encontrar uma forma de convívio com as potências estrangeiras (Kinzer, 2010: 35).

Esse capítulo tratou do primeiro episódio em que as relações entre parte dos cidadãos iranianos (os progressistas e os religiosos islâmicos) e os Estados Unidos foi abalada por conta do golpe de Estado realizado em 1953 contra o primeiro ministro Mossadeq. Todavia, também teve a pretensão de criar as bases teóricas para fomentar o debate a respeito de que esse episódio em 1953 foi estrutural para que houvesse o sequestro da embaixada dos Estados Unidos em 1979 e, também, a Revolução Iraniana. Como destacaram Abrahamian e Kinch:

A própria embaixada foi vista como um símbolo da cumplicidade americana em os eventos de 1953: Os novos líderes do Irã acusaram [...] que os Estados Unidos tinham impôs ao Irã desde 1953 um governo que era opressivo e corruptos, que violavam consistentemente os direitos humanos e eram insensíveis aos valores tradicionais da Sociedade Islâmica do Irã (Takeyh, 2006: 96 apud Abrahamian, 1983: 123, tradução nossa).

A interferência dos EUA em remover ao mesmo tempo um líder popular e o desenvolvimento de um movimento democrático foi uma traição à nova política identitária do Irã, e décadas depois a lembrança desse golpe teria um papel significativo na Revolução Islâmica (Kinch, 2016: 44, tradução nossa).

Por fim, mas não menos relevante, esse trabalho procurou elucidar como independente do governo vigente no Irã ou das suas alianças estrangeiras, os mais prejudicados foram os iranianos, sobretudo, os setores mais marginalizados e subalternos. Os anseios da população iraniana foram diversas vezes tergiversados em prol dos governos vigentes. Desse modo, foi o povo quem mais sofreu com a miséria, fome, falta de moradia e saneamento básico, enquanto alguns dos administradores do Irã viviam cercados por regalias. A sociedade iraniana viveu, ao longo da sua história, sob distintas formas de governos, mas teve em larga medida suas liberdades individuais confiscadas.

\section{BIBLIOGRAFIA}


AZZIMI, Fakhreddin. Iran: The Crises of Democracy - From The Exile of Reza Shah to The Fall of Mussadiq. New York: I.B Taurius \& Co Ltd, 2009.

ABRAHAMIAN, Ervand. IRAN: Between Two Revolutions. New Jersey: Princeton University Press, 1983.

ADICHIE, Chimamanda Ngozi. Vídeo disponível em: http://www.youtube.com/watch?v=ZUtLR1ZWtEY. Acesso em: 10 de outubro de 2013.

ALVES, Tamires Maria. A Construção retórica de uma ameaça - o caso iraniano. REALIS Revista de Estudos Antiutilitaristas e Pós-coloniais - Universidade Federal de Pernambuco. Vol 9, no 2, pp. 145 - 171, 2019. Disponível em: https://periodicos.ufpe.br/revistas/realis/ article/view/242939 Acesso em 10/02/2020.

ALVES, Tamires Maria. Sobre o Irã e o Islam. Revista Breviário de Filosofia Pública - Universidade Federal Fluminense. Número 170, pp. 79 - 86. Dezembro 2018. Disponível em: https://estudoshumeanos.com/2018/12/13/sobre-iran-e-o-islam/ Acesso em: 12/03/2020.

ALVES, Tamires Maria. A Ameaça Iraniana em Xeque: uma leitura pós-colonial sobre o Irã. Dissertação de Mestrado (Relações Internacionais). PUC-Rio. 2013.

AYOOB, Mohammed. Defining Security: a subaltern realist perspective. In Critical Security Studies, edited by Keith Krause and Michael C. Williams. Minneapolis, MN: University of Minnesota Press, 1997.

AYOOB, Mohammed. "Political Islam: Image and Reality". World Policy Journal, September 2004, vol 21 issue (3): pp. 1-14.

AXWORTHY, Michael. Empire of the Mind - A History of Iran. New York: Basic Books, 2008.

BELlAIGUE, Chistopher de. Patriot of Persia. New York: Harper Collins Publishers, 2012.

BYRNE, Malcolm; GASIOROWSKI, Mark J. Mohammad Mossaddeq and the 1953 Coup in Iran. Syracuse University Press, 2004.

COSTA, Renato. A INFLUÊNCIA DOS ULEMÁS XIITAS NAS TRANSFORMAÇÕES POLÍTICAS OCORRIDAS NO IRÃ DURANTE O SÉCULO XX - O WILAYAT AL-FAQIH E O PRAGMATISMO DOS AIATOLÁS COMO INVIABILIZADORES NA EXPANSÃO DA REVOLUÇÃO IRANIANA. Tese de doutorado, FFLCH, USP, 2013.

COOK, Alethia \& ROSHANDEL, Jalil. The United States and Iran: Policy Challenges and Opportunities. New York: PALGRAVE MACMILLAN, 2009.

DARBY, Phillip and PAOLINY, A. J. “Bridging International Relations and Postcolonialism”. 371-397, 1994.

DOTY, Roxanne L. "Foreign policy as social construction: a post-positivist analysis of U.S. counter-insurgency policy in the Philippines". International Studies Quarterly, v. 37, n. 3, p. 297-320, 2003.

GORDON, Matthew. Os grandes líderes: Khomeini. São Paulo: Editora Nova Cultural, 1987. 
FOUCAULT, Michael. A Arqueologia do Saber. Rio de Janeiro: Forense Universitária, 1986. FOUCAULT, Michael. As Palavras e as Coisas. São Paulo: Martins Fontes, 1992. FOUCAULT, Michael. Vigiar e punir. Nascimento da prisão. Petrópolis: Vozes, 1987. HALLIDAY, Fred. Iran: Dictadura y Desarrolo. México D.F: Fondo de Cultura Económica, 1981. HANSEN, Lene. Security as Practice: Discourse Analysis and the Bosnian War. New York. 2006. HIRO, Dilip. Iran under the Ayatollahs. London: Routlefgr \& Kegan Paul, 1985.

JABRI, Vivienne. "Michel Foucault's Analytics of War: The Social, the International, and the Racial". International Political Sociology, v. 1, n. 1, p. 67-81, 2007.

JERVIS, Robert. "Cooperation under security dilemma”. World Politics, v. 30, n. 2, p.167214, 1978.

KEENE, Edward. Beyond the Anarchical Society: Grotius, Colonialism and Order in World Politics. Nova York: Cambridge University Press, 2002.

KEEGAN, John. Uma História da Guerra. São Paulo: Companhia das Letras, 1995

KINCH, Penelope. The US-Iran Relationship: The Impacto f Political Identity on Foreign Policy. Londres, Nova York: I.B Tauris \& Co. Ltd, 2016.

MILLIKEN, Jennifer. "The Study of Discourse in International Relations: A Critique of Research and Methods". In European Journal of International Relations, 1999.

LEWIS, Bernard. O Oriente Médio: do advento do cristianismo aos dias de hoje. São Paulo: Jorge Zahar Editor, 1996.

LEWIS, Bernard. "I'm right, you're wrong, go to hell. Religions and the meeting of civilization". Atlantic Monthly, 2003.

LEWIS, Bernard. O que deu errado no Oriente Médio? Rio de Janeiro: Jorge Zahar Editor, 2002. LIMBERT, John W. Negotiating with Iran: Wresting the Ghosts of History. Washington, D.C: United States Institute of Peace Press. 2009.

MCLEOD, John. Beginning Postcolonialism. New York: Manchester University Press, 2010. MEIHY, Murilo Sebe Bon. Por Devoção à República: Nação e Revolução no Irã entre 1979 e 1988. Dissertação de mestrado, PUC-Rio, 2007.

MESSARI, Nizar. “Existe um novo cenário de segurança internacional?”. In: GOMES, José Maria (org.). América Latina y el (des)orden neoliberal - hegemonia, contrahegemonia, perspectivas. Buenos Aires: CLACSO, p. 131-150, 2003.

MOTTAHEDEH, Roy. The Mantle of the Prophet: Religion and Politics in Iran. Oxford: Taylor and Francis Ltd., 2004. 
NOGUEIRA, João Pontes \& MESSARI, Nizar. Teoria das Relações Internacionais: correntes e debates. Rio de Janeiro: Editora Campus, 2005.

PAHLAVI, Mohamed Reza. The White Revolution of Iran. s/l, The Imperial Pahlavi Library, 1967.

PAZZINATTO, Alceu Luiz \& SENISE, Maria Helena Valente. História Moderna e Contemporânea. São Paulo: Editora Ática, 1994.

PINTO, Paulo. G. H. D. R. "Ritual, etnicidade e identidade religiosa nas comunidades muçulmanas no Brasil”. Revista USP, São Paulo, p. 228-250, setembro/novembro 2005. ISSN 67.

RACHLIN, Nahid. Garotas da Pérsia. Rio de Janeiro: Rocco, 2007.

SAID, Edward W. Orientalismo. São Paulo: Companhia das Letras, 2007.

SAID, Edward W. Cultura e Resistência. Rio de Janeiro: Ediouro Publicações, 2006.

SAID, Edward W. Cultura e Imperialismo. São Paulo: Companhia das Letras, 1995.

SAID, Edward W. A Pena e a Espada. São Paulo: Editora Unesp, 2013.

SALAMA, Mohammad R. Islam: Orientalism and Intellectual History. London - New York: I. B. Tauris, 2011.

SCHMITTCHEN, Dirk; STRITZEL, Holger. Securitization culture and power: rogue states in US and German discourse. In Thierry Balzacq 'Securitization Theory'. London: Routledge, 2011.

THE NEW YORK TIMES. Disponível em: <https: //archive.nytimes.com/www.nytimes. com/library/world/mideast/082053iran-army.html>. Acesso em: 20 de maio de 2012.

U.S DEPARTMENT OF DEFENSE. Disponível em: <http://www.defense.gov/transcripts/ transcript.aspx?transcriptid=4295>. Acesso em 13 de abril de 2013.

US DEPARTMENT OF STATE. Disponível em: <http://www.state.gov/>. Acesso em: 19 de maio de 2013.

WEIL, Josef, (org.). O Oriente Médio na perspectiva marxista. São Paulo: Editora Sundermann, 2007.

WILBER, Donald N. Regime Change in Iran: Overthrow of Premier Mossadeq of Iran. November 1952 - August 1953. CS Historical Paper. № 208. Spokesman, 2006. 
